\title{
Harvesting seed crops: evaluating quality of combined harvesters' operation
}

\author{
Aliksey Podzorov ${ }^{1, *}$, and Igor Pekhalskii ${ }^{1}$ \\ ${ }^{1}$ Federal Research Agro-Engineering Center VIM, 1st Institutskiy proezd, 5, Moscow, 109428, Russia
}

\begin{abstract}
The analysis of the bunker grain collected by various combine harvesters in the conditions of ordinary operation on cleaning of seed crops of grain crops is carried out. Evaluated the purity of the bunker heap, crushing grain, clogged with other seeds. Evaluation of the quality of the bunker heap was carried out on three domestic and seven foreign models of combines. Suggested ways to solve the problem of improving the quality of seed.
\end{abstract}

\section{Introduction}

The main factor in increasing the efficiency of grain production is the use of high-quality seed material. Monitoring of combine harvesting of seed crops, analysis of collected samples and preparation of recommendations on improving the efficiency of combine harvesters' operation for harvesting seed grains of higher reproduction grades of "super elite", "elite" and others is an important step in seed production. At the stage of reproduction of seeds of new varieties, seed crops are of prime importance [1].

When harvesting these crops, seeds of different categories varying from from elite to reproduction grades, are obtained. It is during this stage that the future zoned seed fund of the country is created. It has been found, that seed crops must to be harvested using specialized seed combined harvesters [1-3]. However, where such harvesters are unavailable, conventional combine harvesters are used, originally intended for the harvesting of marketable food or feed grains, featuring some upgrade design of working tools and modified operating modes [4-7].

The authors have not found in the publications of any detailed and systemic information about the features of their operation in general, and even more so in respect of the analysis of the quality of the resulting grain. There are lots private publications upon which it is difficult to judge the state of the general problem of seed production $[8,9]$.

Certainly, in order to have complete information on this matter, all-season large-scale field experiments on harvesting various crops using different harvesters are needed. In modern conditions, for many organizational, technical and financial reasons, such a voluminous work using a uniform methodology is not yet possible. Nevertheless, information even on individual regions is of great scientific and practical interest.

\footnotetext{
* Corresponding author: zhalnin@yandex.ru
} 
The objective of this study is to determine the fractional composition of the bunker grain pile from various combined harvesters during harvesting of seed crops and to give an overall assessment of their compliance with current standards for grain quality.

\section{Experimental}

For evaluating combined harvesters, it was decided to apply a selective method, featuring randomization elements. Samples of bunker grain have been taken in ten farms of three districts of the Vladimir Oblast. A total of ten combined harvesters of different models have been examined: CaseHI -8120 (USA), Claas Lexion-560 (Germany), Claas Mega -370 (360) (Germany), New Holland (USA), RSM Don-1500B (Russia), Massey Fergusson ( USA), Palesse GS12, KKZ Yenisei-950 (Russia), John Deere (USA), RSM Acros-550 (Russia).

The samples of bunker grain heap were taken right in the field, under conditions of an ordinary operation without any special preparation of the harvesters and their operators (Figure 1).

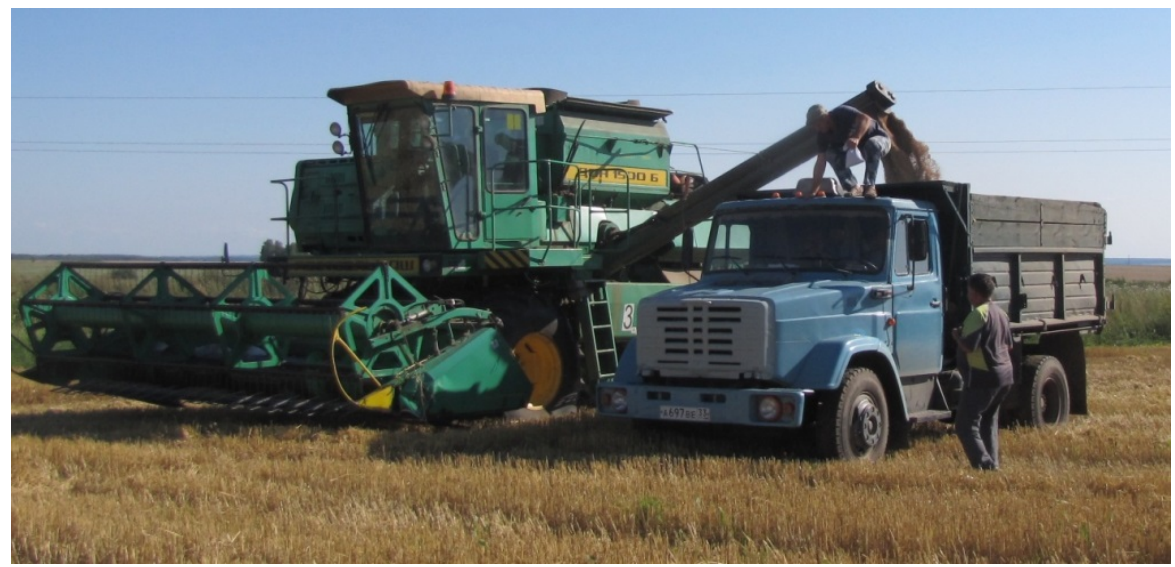

Fig. 1. Agronomist APC "Gavrilovskoe" pick up samples of bunker grain when unloading the bunker of the RSM Don-1500B harvester.

In laboratory conditions, the samples were segregated into two fractions: whole grain and trash weed. As a result, the total debris content in the grain was determined. Weed impurities was additionally segregated into four fractions: crushed grain, grain impurities of other crops, weed seeds and straw impurities. A total of 36 samples were collected and processed, by one and six replicates for each harvester, sampled from the bunker on the run or when unloading grain from the bunker to the truck vehicles. One of the samples, divided into fractions, is shown in Figure 2.

Samples were picked up so as to minimize harvester's idle time during the sampling. Organizationally it was a complicated task, which was often solved only with the help of a farm management officials. This explains the difference in the replications of sampling for each combine (from one to six). That was one of the important features of sampling grain from harvesters in conditions of their ordinary operation. Not all harvester operators agreed to let us take samples from their harvesters. Nevertheless, the error of the results obtained by analyzing the samples did not exceed $10 \%$. 


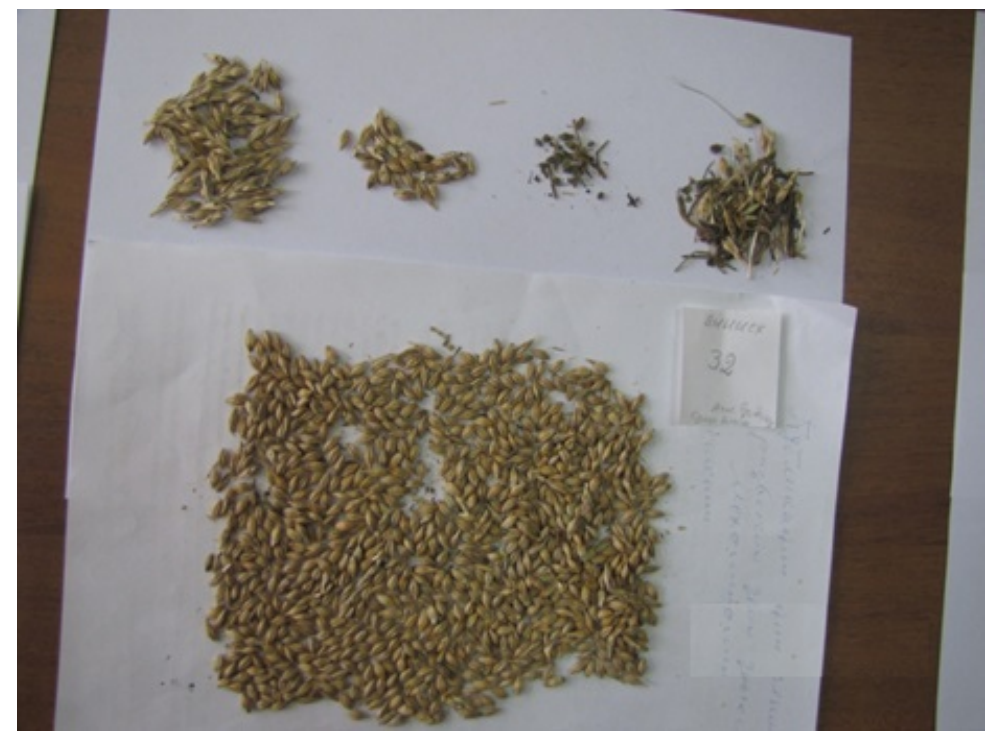

Fig. 2. A portion of bunker grain pile after having been segregated by fractions.

\section{Results and discussion}

This work of this kind has been carried out for the first time. In the open press we found no information on this matter. However, it is in the process of harvesting seed crops that the foundations for obtaining a high-quality seed fund of the country are laid. Requirements for the seed material, underlying this work, were developed by leading research institutes of agriculture and included in GOST R 52325-2005 adopted by the Federal Agency for Technical Regulation and Metrology on March 23, 2005.

The table contains the summary results of the analysis of bunker grain for all the ten harvesters, of which only three were domestic-made: RSM Don-1500B, RSM Acros-550 and $\mathrm{KCH}$ Yenisei-950. This allows to make a conclusion, that there is no centralized policy for the technical support of seed farms. Each farm uses the harvester, which could be purchased for harvesting conventional crops.

Expert analysis has shown, that this situation was typical not only for farms of the Vladimir Oblast, but for many other regions. In terms of grain quality, the best performance was shown by CombineHI-8120 (USA) and Claas Lexion-560 (Germany) harvesters. Impurity of their grain piles is less than $5 \%$, and crushing is close to standard $2 \%$. The grain piles in the bunker of other harvesters had a total debris content ranging from $6.6 \%$ for the KKZ Enisei-950 combine to $9.4 \%$ for the Claas Mega-370, and the grain crushing was $2.2 \%$ (Palesse GS-12) and $4.4 \%$ for Claas Mega-370. In terms of the content of straw impurities in the bunker pile, all harvesters complied with the standard.

Of particular note is the presence in the bunker grain of the grain impurities of other crops (oats, wild oats, etc.), as well as weed seeds. The grain in the bunker of a grain harvester, harvesting seed crops, must be free of such impurities. These crops should not contain weeds and other crops. However, the conducted studies have revealed their presence, which indicates that the culture of farming, agricultural technology and seed production in the farms where the studies were carried out, is not as good as it should be. The level of training of harvester operators should also be improved. A selective examination of the technical condition of harvesters has shown, that not all of them were 
properly prepared for harvesting seed crops. Sealing was not made, threshing and cleaning modes were not optimal. It is advisable to organize training courses for those harvester operators, who work on harvesting seed crops, in every region where there are seed farms.

Despite the small sample size, the advantage of axial-flow (such as Case-HI-8120) and double-drum (such as Yenisei-950) harvesters for harvesting seed crops of cereals is nonetheless notable. This should be taken into account when forming the flee of combined harvesters at seed farms.

Table 1. The results of the analysis of bunker grain samples picked up from various harvesters while harvesting seed crops.

\begin{tabular}{|l|l|l|l|l|l|l|}
\hline \multirow{2}{*}{$\begin{array}{c}\text { Harvester } \\
\text { Model }\end{array}$} & \multicolumn{6}{|c|}{ Content of Impurities in the Bunker Grain } \\
\hline & Impurity, \% & \multicolumn{3}{|c|}{ including } & \multicolumn{3}{l|}{} \\
\hline Claas Lexion-560 (Germany) & 2.1 & 1.0 & 0.6 & 0.3 & 0.2 \\
\hline CaseHI- 8120 (USA) & 4.4 & 2.1 & 1.8 & 0.4 & 0.1 \\
\hline Yenisei-950 (Russia) & 6.6 & 2.4 & 2.7 & 2.4 & 0.2 \\
\hline Don-1500B (Russia) & 6.7 & 3.9 & 2.0 & 0.6 & 0.22 \\
\hline New Holland (CWA) & 6.8 & 3.0 & 2.1 & 0.6 & 0.3 \\
\hline $\begin{array}{l}\text { Palesse GS-12 (Belorus } \\
\text { Russia) }\end{array}$ & 6.8 & 2.2 & 5.1 & 1.0 & 0.5 \\
\hline John Deere 9640 (USA) & 7.5 & 2.9 & 2.8 & 0.8 & 0.4 \\
\hline Acros-550 (Russia) & 8.2 & 3.1 & 1.0 & 2.2 & 0.25 \\
\hline Claas Mega -370 (Germany) & 9.4 & 4.4 & 1.90 & 1.3 & 0.2 \\
\hline $\begin{array}{l}\text { Massey Fergusson Activa } \\
\text { (USE) }\end{array}$ & 9.6 & 4.3 & 2.1 & 2.3 & 0.6 \\
\hline
\end{tabular}

\section{Conclusion}

1. Harvesting seed crops is the most important stage in the formation of the seed fund.

2. The centralized policy in the technical support of seed farms is absent. For harvesting seed crops, each farm uses the combine harvesters that it has managed to acquire to harvest commercial, food and feed grains.

3. From the ten examined models of combine harvesters, only two models comply with the standard in terms of the harvested grain quality.

4. In terms of the quality of grain, axial-flow and double-drum combine harvesters are more advantageous.

5. It is necessary to improve the general culture of farming, agricultural technology of seed cultivation and professional training of harvester operators in terms of harvesting seed crops.

\section{References}

1. V.I. Aniskin, Y.A. Kosmowski, J.F. Nekipelov, N.P. Pedai, A.G. Polyakov, Machines for plant breeding in crop (Moscow:VIM, 2001) pp. 202

2. V.I. Aniskin, J.F. Nekipelov, Mekhanizatsiya opytnykh rabot v selektsii, sortoispytanii $i$ pervichnom semenovodstve zernovykh i zernobobovykh kul'tur (Moscow: VIM, 2001) pp. 200 
3. Yu.V. Erov, T.G. Khadeev, M.D. Isaev, D.Z. Salakhiev, Sistema semenovodstva zernovykh kul'tur (Kazan : Center of innovative technologies, 2005) pp. 328

4. V.A. Domrachev, A.A. Kem, Vestnik Bashkirskogo gosudarstvennogo agrarnogo universiteta, 2, pp. 77-79 (2013)

5. V.P. Elizarov, N.E. Evtyushenkov, M.L. Kryukov, V.F. Rozhin Sel'skiy mekhanizator, 5, pp. 18-19 (2016)

6. E.V. Zhalnin Sel'skiy mekhanizator, 7, pp. 4-5 (2014)

7. A.Yu. Izmaylov, Ya.P. Lobachevskiy, Sel'skokhozyaystvennye mashiny i tekhnologii, 6, pp.6-10 (2013)

8. V.V. Efremova, E.G. Samelik, Nauchnyy zhurnal KubGAU, 106(02), pp. 1-22 (2015)

9. V.M. Bautin, A.A. Aniskin, Mashiny dlya mekhanizatsii selektsionnosemenovodcheskikh rabot v rastenievodstve (Moscow: FGNU «Rosinformagrotekh», 2002) pp. 72 